\title{
Reducing a Lot Sizing Problem with Set up, Production, Shortage and Inventory Costs to Lot Sizing Problem with Set up, Production and Inventory Costs
}

\author{
R. R. K. Sharma, Syed Moize Ali \\ Department of Industrial Engineering, Indian Institute of Technology, Kanpur, India \\ Email: rrks@iitk.ac.in
}

How to cite this paper: Sharma, R.R.K. and Ali, S.M. (2017) Reducing a Lot Sizing Problem with Set up, Production, Shortage and Inventory Costs to Lot Sizing Problem with Set up, Production and Inventory Costs. American Journal of Operations Research, 7, 282-284.

https://doi.org/10.4236/ajor.2017.75020

Received: May 27, 2017

Accepted: August 29, 2017

Published: September 1, 2017

Copyright $\odot 2017$ by authors and Scientific Research Publishing Inc. This work is licensed under the Creative Commons Attribution-NonCommercial International License (CC BY-NC 4.0). http://creativecommons.org/licenses/by-nc/4.0/ (c) (i) (8) Open Access

\begin{abstract}
We reduce lot sizing problem with (a) Set Up, Production, Shortage and Inventory Costs to lot sizing problem with (b) Set Up, Production, and Inventory Costs. For lot sizing problem (as in (b)), Pochet and Wolsey [1] have given already integral polyhedral with polynomial separation where a linear program yield "integer" solutions. Thus problem (b) which we have created can be more easily solved by methods available in literature. Also with the removal of shortage variables is an additional computational advantage.
\end{abstract}

\section{Keywords}

Lot Sizing Problem, Wagner-Whitin Costs

\section{Introduction}

Capacitated single item lot sizing problem (CLSP) with setup, backorders and inventory is a well studied problem (see Wolsey [2] for a detailed literature review). Pochet and Wolsey [1] gave several valid inequalities of uncapacitated LSP which resulted in a reformulation (linear program) that can be solved much more easily (compared to effort required to solve the 0-1 mixed integer programming formulation of CLSP). We use formulation of Kumar [3], and pose capacitated single item lot sizing problem (CLSP) with setup, backorders and inventory as a single item lot sizing problem with set up, production and inventory problem. We can then reformulate it by using valid inequality given in Pochet and Wolsey [1].

\section{Problem Formulation}

\section{Indices Used}


$t$. Set of Time period from $1, \cdots, T$.

\section{Constant:}

$f_{i}$ fixed cost in time period " $t$ ";

$p_{t}$ : per unit variable (production) cost in time period " $t$ ";

$c_{i}$ : production capacity in time period " $t$ ";

$D_{t}$ : demand in time period " $t$ ";

$h_{i}$ : per unit inventory carrying cost in time period " $t$ ";

$s h_{i}$ per unit shortage cost in time period " $t$ ".

\section{Definition of Variables}

$x_{i}$ : amount produced in time period " $t$ ";

$y_{i}: 1$, if machine setup to produce in time period " $t$ ",

0 , otherwise;

$s_{t}$ : shortage in time period " $t$ ";

$I_{i}$ : Inventory in time period " $t$ ".

\section{Model A1:}

$$
\text { Minimize } Z=\sum_{t=1}^{T} f_{t} * y_{t}+\sum_{t=1}^{T} p_{t} * x_{t}+\sum_{t=1}^{T} h_{t} * I_{t}+\sum_{t=1}^{T} s h_{t} * s_{t}
$$

s.t.

$$
\begin{aligned}
& I_{0}+\sum_{t=1}^{t_{1}} x_{t}+s_{t_{1}}=\sum_{t=1}^{t_{1}} D_{t}+I_{t_{1}} \text { for all } t_{1}=1, \cdots, T \\
& \qquad x_{t} \leq c_{t} \cdot y_{t}, \quad \forall t=1, \cdots, T \\
& x_{t}, I_{t}, s_{t} \geq 0 ; \text { and } y_{t}=(0,1)
\end{aligned}
$$

This formulation is based on the formulation given for the location-distributed problem with shortages and inventory by Kumar [3]. Traditionally the problem is formulated as (Wolsey [2], p. 1593) given below:

\section{Model A2:}

$\operatorname{Min}(1)$

$$
x_{t}+s_{t}-s_{t-1}=D_{t}+\left(I_{t}-I_{t-1}\right), \forall t=1, \cdots, T
$$

and (3) \& (4).

In model (1), we substitute

$x_{t}=c_{t} \cdot y_{t}$ in (1) and (2), to get

$S_{t 1}=\sum_{t=1}^{t_{1}} D_{t}+I_{t 1}-I_{0}-\sum_{t=1}^{t_{1}} c_{t} * y_{t}$ for all $t_{1}=1, \cdots, T$

(6) is substituted in (1) along with $x_{t}=c_{t}^{*} y_{t}$ to get following:

Model A3:

$$
\begin{aligned}
& \sum_{t=1, \cdots, T}\left(f_{t}+\left(p_{t} * c_{t}\right)\right) * y_{t}+\sum_{t=1, \cdots, T}\left(h_{t} * I_{t}\right) \\
& +\sum_{t=1, \cdots, t_{1}}\left(s h_{t 1} *\left(\sum_{t=1, \cdots, t_{1}} D_{t}+I_{t 1}-I_{0}-\sum_{t=1, \cdots, t_{1}}\left(c_{t} * y_{t}\right)\right)\right) \\
& I_{t} \geq 0 \text {; and } y_{t}=(0,1)
\end{aligned}
$$

It can be easily seen that coefficient of $I_{t}$ is positive; and coefficient of $y_{t}$ can be 
positive, negative or zero. It can be easily seen that Model A3 is a lot sizing problem without shortage variables as in (b). Now we can apply the methods of reformulation and valid inequalities developed as given in (1).

\section{Conclusion}

Thus we show that a lot sizing problem with set up, production, inventory and shortage costs is reduced to a lot sizing problem with set up, production and inventory costs. This is possible due to new formulation given in Kumar [3]. Also then reformulation-based methods given in [1] and [2] can be fruitfully applied. This is the useful contribution given in this paper.

\section{References}

[1] Pochet, Y. and Wolsey L.A. (1994) Polyhedra for Lot Sizing with Wagner-Whitin Costs. Math Programming, 67, 207-323. https://doi.org/10.1007/BF01582225

[2] Wolsey, L.A. (2002) Solving Multi-Item Lot-Sizing Problems with an MIP Solver Using Classification and Reformulation. Management Science, 48, 1587-1602. https://doi.org/10.1287/mnsc.48.12.1587.442

[3] Kumar, V. (2012) Equal Distribution of Shortages in Supply Chain of Food Corporation of India: Using Lagrangian Relaxation Methodology. Master's Thesis, Indian Institute of Technology, Kanpur. (Unpublished)

Submit or recommend next manuscript to SCIRP and we will provide best service for you:

Accepting pre-submission inquiries through Email, Facebook, LinkedIn, Twitter, etc. A wide selection of journals (inclusive of 9 subjects, more than 200 journals) Providing 24-hour high-quality service User-friendly online submission system Fair and swift peer-review system Efficient typesetting and proofreading procedure Display of the result of downloads and visits, as well as the number of cited articles Maximum dissemination of your research work

Submit your manuscript at: http://papersubmission.scirp.org/

Or contact ajor@scirp.org 